\title{
A shift in the virulence potential of Corynebacterium pseudotuberculosis biovar ovis after passage in a murine host demonstrated through comparative proteomics
}

\author{
Wanderson M. Silva ${ }^{1,4,5}$, Fernanda A. Dorella', Siomar C. Soares ${ }^{1}$, Gustavo H. M. F. Souza ${ }^{3}$, Thiago L. P. Castro',
} Núbia Seyffert ${ }^{1}$, Henrique Figueiredo ${ }^{6}$, Anderson Miyoshi ${ }^{1}, Y_{v e s}$ Le Loir ${ }^{4,5}$, Artur Silva ${ }^{2}$ and Vasco Azevedo ${ }^{*}$

\begin{abstract}
Background: Corynebacterium pseudotuberculosis biovar ovis, a facultative intracellular pathogen, is the etiologic agent of caseous lymphadenitis in small ruminants. During the infection process, C. pseudotuberculosis changes its gene expression to resist different types of stresses and to evade the immune system of the host. However, factors contributing to the infectious process of this pathogen are still poorly documented. To better understand the $C$. pseudotuberculosis infection process and to identify potential factors which could be involved in its virulence, experimental infection was carried out in a murine model using the strain 1002_ovis and followed by a comparative proteomic analysis of the strain before and after passage.

Results: The experimental infection assays revealed that strain 1002_ovis exhibits low virulence potential. However, the strain recovered from the spleen of infected mice and used in a new infection challenge showed a dramatic change in its virulence potential. Label-free proteomic analysis of the culture supernatants of strain 1002_ovis before and after passage in mice revealed that 118 proteins were differentially expressed. The proteome exclusive to the recovered strain contained important virulence factors such as CP40 proteinase and phospholipase D exotoxin, the major virulence factor of C. pseudotuberculosis. Also, the proteome from recovered condition revealed different classes of proteins involved in detoxification processes, pathogenesis and export pathways, indicating the presence of distinct mechanisms that could contribute in the infectious process of this pathogen.
\end{abstract}

Conclusions: This study shows that C. pseudotuberculosis modifies its proteomic profile in the laboratory versus infection conditions and adapts to the host context during the infection process. The screening proteomic performed us enable identify known virulence factors, as well as potential proteins that could be related to virulence this pathogen. These results enhance our understanding of the factors that might influence in the virulence of C. pseudotuberculosis.

Keywords: Corynebacterium pseudotuberculosis, Bacterial label-free proteomic, Caseous lymphadenitis, Bacterial virulence, Serial passage, Extracellular proteins

\footnotetext{
* Correspondence: vasco@icb.ufmg.br

'Departamento de Biologia Geral, Instituto de Ciências Biológicas,

Universidade Federal de Minas Gerais, Belo Horizonte, Minas Gerais, Brazil

Full list of author information is available at the end of the article
} 


\section{Background}

Corynebacterium pseudotuberculosis biovar ovis is a Gram-positive facultative intracellular pathogen. It is the etiologic agent of Caseous Lymphadenitis (CLA) in small ruminants, a disease characterized by abscess formation in lymph nodes and internal organs [1]. Cases of human infection caused by $C$. pseudotuberculosis have been reported and are associated with occupational exposure [1]. CLA is globally distributed and causes significant economic losses in goats, and sheep herds [2]. The pathogenic process of $C$. pseudotuberculosis in the host comprises two phases: (i) initial colonization and replication in lymph nodes that drain the site of infection, which is associated with pyogranuloma formation, and (ii) a secondary cycle of replication and dissemination via the lymphatic or circulatory systems. This dissemination is promoted by the action of phospholipase $\mathrm{D}$ (PLD) exotoxin, the major virulence factor of C. pseudotuberculosis, which allows this pathogen to contaminate visceral organs and lymph nodes, where it ultimately induces lesion formation [3-5].

Exported proteins reportedly favor the infection process in pathogenic bacteria; this class of proteins is involved in adhesion and invasion of host cells, nutrient acquisition, toxicity, and in the evasion of the host immune system [6]. Different strategies like the transposon mutagenesis have been adopted to identify C. pseudotuberculosis biovar ovis exported proteins [7]. Additionally, comparative proteomics has been applied to characterize the extracellular proteome of C. pseudotuberculosis biovar ovis, as well as, the extracellular immunoproteome (strains C231_ovis and 1002_ovis) [8-11]. In these studies, some proteins of the strain 1002_ovis, suspected to be virulence factors, were not detected suggesting this strain presents a low virulence. The surface proteome of C. pseudotuberculosis biovar ovis was also characterized using bacterial strains isolated from the lymph nodes of naturally infected sheep. This proteomic analysis allowed the identification of proteins that could favor the survival of this pathogen during the chronic phase of CLA [12].

The experimental passage of bacterial pathogens through in vitro or in an in vivo model is a strategy that has been applied to evaluate the virulence potential of several pathogens. By generating a confrontation between the pathogen and the dynamic network of host factors, including the immune system components, it helps to identify bacterial factors involved in virulence [12-19]. In this study, the strain 1002_ovis was experimentally inoculated in mice $[20,21]$ to identify factors which could contribute to virulence in C. pseudotuberculosis biovar ovis. Comparative proteomics of the culture supernatant from this strain collected before and after the experimental passage in mice was carried out to identify factors that might contribute to virulence of 1002_ovis.

\section{Methods}

\section{Bacterial strains and growth conditions}

The C. pseudotuberculosis biovar ovis strain 1002 (1002_ovis) was isolated from a goat in Brazil; this strain was cultivated under standard conditions in brain-heart infusion broth (BHI-HiMedia Laboratories Pvt. Ltd., India) at $37{ }^{\circ} \mathrm{C}$. When necessary, $1.5 \%$ of agar was added to the medium for a solid culture. For extracellular proteomic analyses, 1002_ovis was grown in a chemically defined medium $(\mathrm{CDM})\left[\left(\mathrm{Na}_{2} \mathrm{HPO}_{4 \_\_} 7 \mathrm{H}_{2} \mathrm{O}(12.93 \mathrm{~g} / \mathrm{L}), \mathrm{KH}_{2} \mathrm{PO} 4\right.\right.$ $(2.55 \mathrm{~g} / \mathrm{L}), \mathrm{NH}_{4} \mathrm{Cl}(1 \mathrm{~g} / \mathrm{L}), \mathrm{MgSO}_{4} \_7 \mathrm{H}_{2} \mathrm{O}(0.20 \mathrm{~g} / \mathrm{L}), \mathrm{CaCl}_{2}$ (0.02 $\mathrm{g} / \mathrm{L})$ and $0.05 \%(\mathrm{v} / \mathrm{v})$ Tween 80], 4\% (v/v) MEM Vitamins Solution (Invitrogen, Gaithersburg, MD, USA), 1\% (v/v) MEM Amino Acids Solution (Invitrogen), 1\% (v/v) MEM Non-Essential Amino Acids Solution (Invitrogen), and $1.2 \%(\mathrm{w} / \mathrm{v})$ glucose at $37^{\circ} \mathrm{C}[22]$.

\section{Experimental infection of strain 1002_ovis in a murine model (in vivo assay)}

The standardization of the parameters for infection was performed according to Moraes et al. [20] and Ribeiro et al. [21]. Female BALB/c mice between six and eight weeks old were used in all experiments. They were provided by the Animal Care Facility of the Biological Sciences Institute from the Federal University of Minas Gerais and were handled by the guidelines of the UFMG Ethics Committee on Animal Testing (Permit Number: CETEA 103/2011). For the bacterial passage assay using the murine model, two groups of three mice each was infected via intraperitoneal injection with $10^{6}$ colony forming units (CFU) of strain 1002_ovis. Thirty-six hours after infection, all animals were sacrificed. Their spleens were aseptically removed to recover the bacterial strain, as described below: the spleen removed from each animal was then, individually macerated in sterile saline solution $\left(0.9 \% \mathrm{NaCl}_{2}\right)$, seeded onto $\mathrm{BHI}$ agar plates and incubated for $48 \mathrm{~h}$ at $37{ }^{\circ} \mathrm{C}$. Subsequently, one recovered bacterial colony was cultured in BHI broth. The recovered bacteria were then referred to as Recovered (Rc). For the bacterial virulence assay, we used the freshly recovered bacteria and bacteria that did not contact the murine host as a control, which is referred to as Control (Ct). Groups of five mice were infected with $\mathrm{Rc}$ and $\mathrm{Ct}$, via intraperitoneal injection of a suspension containing $10^{6} \mathrm{CFU}$ or $10^{5}$ CFU. The animals' survival rates were calculated and represented in GraphPad Prism v.5.0 (GraphPad Software, San Diego, CA, USA) using the Kaplan-Meier survival function. The results of 1002_ovis CFU count in the organs were calculated using the two-way ANOVA test.

\section{Preparation of proteins from culture filtrates for proteome analysis}

For proteomic analysis, the $\mathrm{Ct}$ and Rc (three independently recovered colonies) that was obtained from infected 
mice spleens as described above were grown in CDM at $\mathrm{OD}_{600}=0.8$. The cultures were then centrifuged for $20 \mathrm{~min}$ at $2700 \times \mathrm{g}$. The supernatants were then filtered using $0.22-\mu \mathrm{m}$ filters, $30 \%(\mathrm{w} / \mathrm{v})$ ammonium sulfate was added to the samples, and the $\mathrm{pH}$ of the mixtures was adjusted to 4.0. Next, $20 \mathrm{~mL} \mathrm{~N}$-butanol was added to each sample. The samples were centrifuged for $10 \mathrm{~min}$ at 1350 $\mathrm{xg}$ and $4{ }^{\circ} \mathrm{C}$. The interfacial precipitate was collected and resuspended in $1 \mathrm{~mL}$ of $20 \mathrm{mM}$ Tris- $\mathrm{HCl} \mathrm{pH} 7.2$ [23]. Finally the concentration protein was determined by Bradford method [24].

\section{D-PAGE electrophoresis and Mass Spectrometry}

The 2-DE procedure and in-gel protein digestion were performed as described previously $[9,10]$. Approximately $300 \mu \mathrm{g}$ of the protein extract from of each condition was dissolved in rehydration buffer (Urea $7 \mathrm{M}$, thiourea $2 \mathrm{M}$, CHAPS $2 \%$, Tris-HCl $40 \mathrm{mM}$, bromophenol blue $0.002 \%$, DTT $75 \mathrm{mM}$, IPG Buffer 1\%). Samples were applied to $18 \mathrm{~cm} \mathrm{pH} \mathrm{3-10} \mathrm{N.L} \mathrm{strips} \mathrm{(GE} \mathrm{Healthcare,} \mathrm{Pittsburgh,}$ USA). Isoelectric focusing (IEF) was performed using the apparatus IPGphor 2 (GE Healthcare) under the following voltages: $100 \mathrm{~V} 1$ h, $500 \mathrm{~V} 2 \mathrm{~h}, 1000 \mathrm{~V} 2$ h, 10,000 V 3 h, $10,000 \mathrm{~V} 6 \mathrm{~h}, 500 \mathrm{~V} 4 \mathrm{~h}$. The IPG strips were placed on $12 \%$ acrylamide/bis acrylamide gels in an Ettan DaltSix II system (GE Healthcare). The gels were stained with Coomassie Blue G-250 staining solution, and 2-DE gels were scanned using an Image Scanner (GE Healthcare). The Image Master 2D Platinum 7 (GE Healthcare) software was used to analyze the generated images and all spots were matched and analyzed by gel-to-gel comparison. The quantification of the spots was calculated according percentage volume (\% Vol) and spots with reproducible changes in abundance were considered to be differentially expressed. Protein spots were excised from the gels, and in-gel digestion was carried out using trypsin enzyme (Promega, Sequencing Grade Modified Trypsin, Madison, WI, USA). The peptides were then desalted and concentrated using ZIP TIP C18 tips (Eppendorf).

The samples were subsequently analyzed for MS and MS/MS modes, using an MALDI-TOF/TOF mass spectrometer Autoflex IIITM (Bruker Daltonics, Billerica USA). The equipment was controlled in a positive/reflector way using the Flex-ControlTM software (Brucker Daltonics). External calibration was performed using peptide standards samples (angiotensin II, angiotensin I, substance P, bombesin, ACTH clip 1-17, ACTH clip 18-39, somatostatin 28, bradykinin Fragment 1-7, Renin Substrate tetra decapeptide porcine) (Bruker Daltonics). The peptides were added to the alpha-cyano-4-hydroxycinnamic acid matrix, applied on an Anchor-ChipTM 600 plate (Brucker Daltonics) and analyzed by Autoflex III. The search parameters were as follows: enzyme; trypsin; fixed modification, carbamidomethylation (Cys); variable modifications, oxidation (Met); mass values, monoisotopic; maximum missed cleavages, 1 ; and peptide mass tolerance of $0.005 \% \mathrm{Da}(50 \mathrm{ppm})$. The results obtained by MS/MS were used to identify proteins utilizing the MASCOT_ (http://www.matrixscience.com) program and compared with the genomic data of the Actinobacteria class deposited in the NCBI nr database.

\section{D nanoUPLC-HDMSE data acquisition and Data Processing}

The protein extracts from three biological replicates of each condition were concentrated using spin columns with a $10 \mathrm{kDa}$ threshold (Millipore, Billerica, MA, USA) to perform the label-free proteomic analysis. The protein was denatured $\left(0.1 \%\right.$ RapiGEST SF at $60{ }^{\circ} \mathrm{C}$ for $\left.15 \mathrm{~min}\right)$ (Waters, Milford, CA, USA), reduced (10 mM DTT), alkylated (10 $\mathrm{mM}$ iodoacetamide) and enzymatically digested with trypsin (Promega). The digestion process was stopped by adding $10 \mu \mathrm{L}$ of $5 \%$ TFA (Fluka, Buchs, Germany), and glycogen phosphorylase (Sigma, Aldrich, P00489) was added to the digested samples after digest at $20 \mathrm{fmol} . \mathrm{uL}^{-1}$ as an internal standard for normalization. Each replicate was injected using a two-dimensional reversed phase (2D RPxRP) nanoUPLC-MS (Nano Ultra Performance Liquid Chromatography Mass Spectrometry) approach with 171 multiplexed high definition mass spectrometry (HDMSE) label-free quantitation [25]. Qualitative and quantitative experiments were performed using both a $1 \mathrm{~h}$ reversed phase gradient from $7 \%$ to $40 \%$ (v/v) acetonitrile $\left(0.1 \% \mathrm{v} / \mathrm{v}\right.$ formic acid) at $500 \mathrm{~nL} \cdot \mathrm{min}^{-1}$ and a nanoACQUITY UPLC 2D RPxRP Technology system [26]. A nanoACQUITY 174 UPLC HSS T3 $1.8 \mu \mathrm{m}$, $75 \mu \mathrm{m} \times 15 \mathrm{~cm}$ column $(\mathrm{pH} 3)$ was used with an RP XBridge BEH130 C18 $5 \mu \mathrm{m} 300 \mu \mathrm{m}$ x $50 \mathrm{~mm}$ nanoflow column ( $\mathrm{pH} 10)$. Typical on-column sample loads were $250 \mathrm{ng}$ of the total protein digests for each of the 5 fractions (250 ng/fraction/load). All analyses were performed using nano electrospray ionization in the positive ion mode nanoESI $(+)$ and a NanoLockSpray (Waters, Manchester, UK) ionization source. The mass spectrometer was calibrated using an MS/MS spectrum of [Glu1]-Fibrinopeptide B human (Glu-Fib) solution (100 fmol.uL-1) delivered through the NanoLockSpray source reference sprayer. Multiplexed data-independent (DIA) scanning with additional specificity and selectivity for non-linear 'T-wave' ion mobility (HDMSE) experiments were performed using a Synapt G2-S HDMS mass spectrometer (Waters, Manchester, UK).

Following the identification of proteins, the quantitative data were packaged using dedicated algorithms [27] and searching against a database with default parameters to account for ions [28]. The databases used were reversed on-the-fly during the database queries and appended to the original database to assess the false positive rate during identification. For proper spectra 
processing and database searching conditions, the ProteinLynxGlobalServer v.2.5.2 (PLGS) with IdentityE and ExpressionE informatics v.2.5.2 (Waters, Manchester, UK) was used. UniProtKB (release 2013_01) with manually reviewed annotations was used, and the search conditions were based on taxonomy (Corynebacterium pseudotuberculosis). One missed cleavage by trypsin was allowed be up to 1 and various modifications as carbamidomethyl (C), Acetyl N terminal, phosphoryl (STY) and oxidation (M) were allowed [29]. The proteins collected were organized by the PLGS ExpressionE tool algorithm into a statistically significant list that corresponded to higher or lower regulation ratios between the different groups. For protein quantitation, we used the PLGS v2.5.2 software with the IdentifyE algorithm using the Hi3 methodology. The search threshold to accept each spectrum was the default value for a false discovery rate $4 \%$. The quantitation values were averaged over all samples, and the standard deviations of $p<0.05$, which were determined using the ExpressionE software, refer to the differences between biological replicates.

\section{Bioinformatic analysis}

The proteins identified in 1002_ovis under both conditions were analyzed using the following prediction tools: SecretomeP 2.0 server, to predict proteins exported from non-classical systems (positive prediction score greater than to 0.5) [30] and PIPs software, to predict proteins in the pathogenicity islands [31]. Gene ontology (GO) functional annotations were generated using the Blast2GO tool [32].

\section{Results}

The main objective of this study was to assay the virulence of 1002_ovis in a murine model after passage through mice. We thus carried out an in vivo survival assay using $\mathrm{BALB} / \mathrm{c}$ mice infected with bacteria that did not contact with murine model $(\mathrm{Ct})$ and bacteria recovered $(\mathrm{Rc})$ from mice spleens. In this assay using an infection inoculum of $10^{6} \mathrm{CFU}$, all the animals infected with Rc died within $48 \mathrm{~h}$ after infection (Fig. 1a). On the other hand, the control group, infected with $\mathrm{Ct}$, survived the evaluation period (6 days). Similarly, in an assay with a lower infective dose $\left(10^{5} \mathrm{CFU}\right)$, a $100 \%$ mortality was observed four weeks post infection with the recovered bacteria (Fig. 1b). Comparison of the $\mathrm{Ct}$ and Rc numbers isolated from the spleen within five days of infection (Fig. 1c) showed that the serial passage process affected the potential for spleen colonization during the infection. After four weeks of infection in the assay with $10^{5} \mathrm{CFU}$, bacteria were isolated from the spleen, liver, left and right kidney, only in mice infected with Rc (Fig. 1d). Finally, regarding the clinical signs, in the assay using $10^{5} \mathrm{CFU}$, caseous lesions were detected in different organs (liver, left kidney and right kidney) of all the animals infected only with Rc (data not shown). Altogether, these results showed that the serial passage process in a murine model increased the virulence potential of strain 1002_ovis. In addition, these results confirmed the low virulence of this strain, which was previously suggested based on the composition of its extracellular proteome [8-10].

After passage in $\mathrm{BALB} / \mathrm{c}$ mice, a dramatic change in the virulence potential of strain 1002_ovis was observed. We thus hypothesized that this phenotypic change was visible at the proteome level since C. pseudotuberculosis virulence relies on the production of a proteinaceous virulence factor. Thus, considering the importance of extracellular proteins for bacterial virulence, the proteomic analysis was conducted on the extracellular proteomes of 1002_ovis recovered from infected mice spleens in comparison to the control condition, using two proteomics approaches: 2-DE and 2D nanoUPLC-HDMS ${ }^{\mathrm{E}}$. The electrophoretic resolution of the extracellular protein extract of $\mathrm{Ct}$ and $\mathrm{Rc}$ condition allowed the visualization of spots distributed over $\mathrm{pH} 3-10$ (Fig. 2). A total of 14 spots were found to be differentially expressed between $\mathrm{Ct}$ and Rc condition, these spots were excised out of the gel, and identified by MS/MS (Table 1). In the LC/MS analysis, we used the label-free quantitative proteomic to evaluate the relative difference between the proteome of $\mathrm{Rc}$ and $\mathrm{Ct}$ condition. In this analysis, only proteins which presented $p<0.05$ and differential expression ( $\log 2$ ratios) equal or greater than a factor of 1.2 were considered, as described previously [33]. We detected a total of 118 expressed differentially proteins, between $\mathrm{Ct}$ and Rc condition (Fig. 3) (Table 2 and Additional file 1). Also, 48 proteins were assigned only to $\mathrm{Ct}$ (Additional file 2) and 32 proteins were exclusive to Rc (Table 3) The information about sequence coverage and a number of identified peptides for each protein sequence identified, as well as the information about the native peptide are available at Additional file 3: Table S3.

The proteins identified in both conditions were analyzed by SecretomeP [29] to assess whether these proteins could be exported by non-classical secretion systems. Among the expressed differentially proteins $31 \%$ (37 proteins) were predicted as secreted through non-classical secretion systems. In turn, when analyzed the exclusive proteome of each condition 19\% (6 proteins) and $27 \%$ (13 proteins) were considered to be exported by non-classical secretion systems for recovered and control condition, respectively. The PIPS tool was used to evaluate whether the genes that encode the proteins which were differentially expressed and identified in the exclusive proteome of the Rc condition are included in predicted pathogenicity islands. According these analysis 16 proteins was encoded by genes located on a predicted pathogenicity island; these 
a

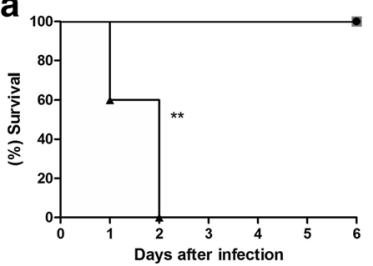

C

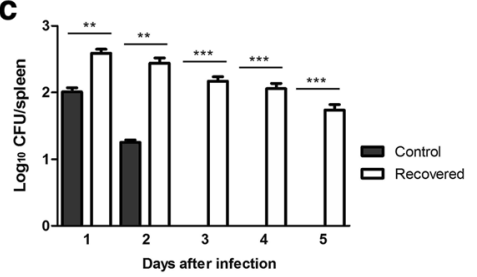

b

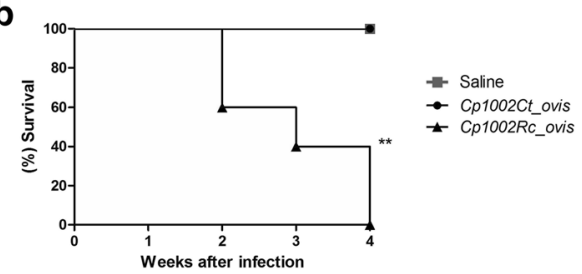

d

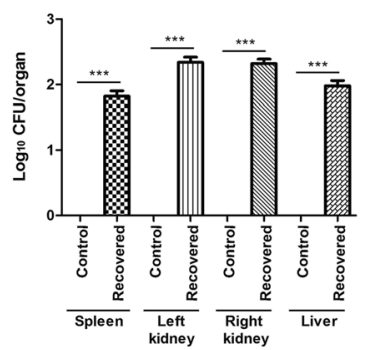

Fig. 1 Survival of Balb/C mice infected with strain 1002_ovis. a The survival rate was measured to determine the virulence profile of strain 1002_ovis control and recovered in mice infected with $10^{6} \mathrm{CFU}$ of bacteria $\mathrm{Ct}=$ control condition, $\mathrm{Rc}$ recovered condition. $\mathbf{b}$ Survival rates of mice infected with $10^{5}$ CFU of Ct and Rc. c CFU in the spleen of BALB/c mice infected with control and recovered condition for the first five days of infection. $\mathbf{d}$ CFU in the different organs (spleen, left kidney, right kidney and liver) of BALB/c mice infected with control and recovered condition after four weeks of infection. The mortality rates were measured daily. Results represent three independent experiments. $P$ values of $<0.05$ were considered to be statistically significant, and asterisks indicate statistically significant differences

proteins are related to cellular metabolism, pathogenesis, transport pathway, stress response and unknown function (Additional file 4). To classify the proteins identified in functional groups, we used the Blast2Go tool [31]; according to this analysis, the proteins were grouped into 17 biological processes (Fig. 4). Among these proteins, we identified processes that are directly involved in bacterial virulence, such as protein transport, pathogenesis, cell adhesion and stress response (Table 2).

Important factors directly linked to C. pseudotuberculosis virulence, like the PLD phospholipase, as well as, the $\mathrm{CP} 40$ protease were detected only in the proteome of recovered 1002_ovis (Tables 1 and 3). Also, components of several secretion systems were also activated in the bacteria recovered. These include proteins related to hemin uptake, ATP-binding cassette $(\mathrm{ABC})$ transporters and the Opp transporter, like OppA, OppC, and OppD. Proteins related to detoxification process were also specifically identified in the $\mathrm{Rc}$ supernatant: e.g. the glutaredoxin-like protein $\mathrm{NrdH}$, which belongs to the $\mathrm{NrdH}$-redoxins, a family of small protein disulfide oxidoreductases [34], mycothiol glutathione reductase present in Actinobacteria [35] and copper resistance protein CopC (Tables 2 and 3). In addition, we have identified 31 proteins in the recovered condition that also were detected in a strain of C. pseudotuberculosis isolated directly from ovine lymph nodes [12] (Tables 2 and 3). Proteins involved in the resistance to antimicrobial agents, such as penicillinbinding proteins, metallo-beta-lactamase, and penicillinbinding protein transpeptidase and proteases like Clp protease involved in the expression of cytotoxins in
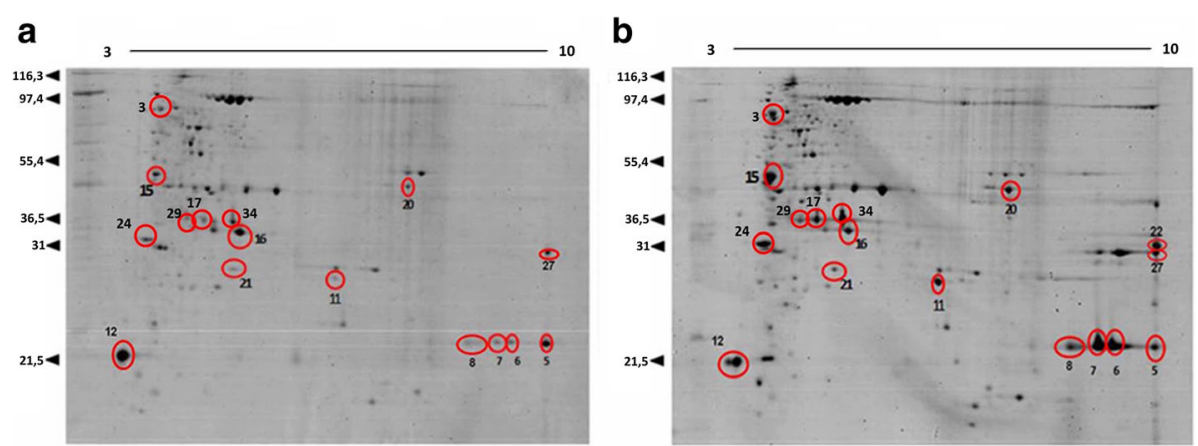

Fig. 2 Two-dimensional electrophoresis of the extracellular proteins 1002_ovis after following passage process: a Control condition. b Recovered condition. Red circle: spot proteins identified by MS/MS 
Table 1 List of proteins identified in 1002_ovis control and recovered by 2D-PAGE-MS/MS

\begin{tabular}{lllllll}
\hline Spot & Description & Accession & MW(kDa)/p.I & $\begin{array}{l}\text { Peptides } \\
\text { Number }\end{array}$ & Mascot Score & Molecular function \\
\hline $5,6,7$ & Hypothetical protein & ADL20032 & $24.30 / 9.24$ & 2 & 189 & Unknown function \\
11,29 & Trypsin-like serine protease & ADL20653 & $25.72 / 6.49$ & 2 & 96 & Serine-type endopeptidase activity \\
15 & Hypothetical protein & ADL21714 & $42.04 / 5.22$ & 4 & 159 & Catalytic activity \\
20,34 & Corynomycolyl transferase & ADL21610 & $41.80 / 7.05$ & 2 & 58 & Transferase activity \\
16 & Cytochrome c oxidase sub II & ADL21302 & $40.33 / 6.03$ & 2 & 96 & Cytochrome-c oxidase activity \\
21 & Hypothetical protein & ADL21914 & $12.30 / 5.04$ & 2 & 53 & Unknown function \\
12 & Hypothetical protein & ADL19922 & $19.86 / 4.30$ & 2 & 145 & Calcium ion binding \\
8 & Hypothetical protein & ADL09626 & $24.30 / 9.24$ & 3 & 228 & Unknown \\
27 & Hypothetical protein & ADL20508 & $31.62 / 9.52$ & 2 & 66 & Unknown \\
22 & Phospholipase D & ADL19935 & $34.09 / 8.91$ & 4 & 286 & Sphingomyelin phosphodiesterase \\
3 & Enolase & ADL20605 & $45.17 / 4.68$ & 3 & 271 & D activity \\
17 & Trehalose corynomycolyl transferase B & ADL21814 & $36.67 / 6.90$ & 5 & 245 & Phosphopyruvate hydratase activity \\
& & & & & & Transferase activity, transferring acyl \\
24 & Hypothetical protein & ADL21714 & $40.90 / 5.05$ & 3 & 190 & Catalytic activity
\end{tabular}

Staphylococcus aureus and Listeria monocytogenes [36, 37] were found induced in Rc supernatant.

\section{Discussion}

To investigate the protein factors that could influence the adaptive processes of C. pseudotuberculosis biovar ovis during the infection process, we combined a unique bacterial passage experiment in mice with proteomic analyses of 1002_ovis culture supernatants, collected before and after passage. In the first analysis, we observed that strain 1002_ovis (isolated from caprine) exhibited a low virulence potential, which is consistent with previous reports indicating the low virulence potential of this strain [38, 39]. Although a recent in silico analysis of the 1002_ovis genome predicted various genes involved in virulence [40], studies examining the exoproteome of this strain under laboratory growth conditions failed to detect many of these virulence proteins (e.g., PLD exotoxin or proteins involved in the pathway of cell invasion, detoxification) [8-10].

One explanation for this relies on the fact that after being first isolated, strains 1002_ovis have been maintained, in vitro, under laboratory conditions with extensive passages on the culture medium, which may alter the gene

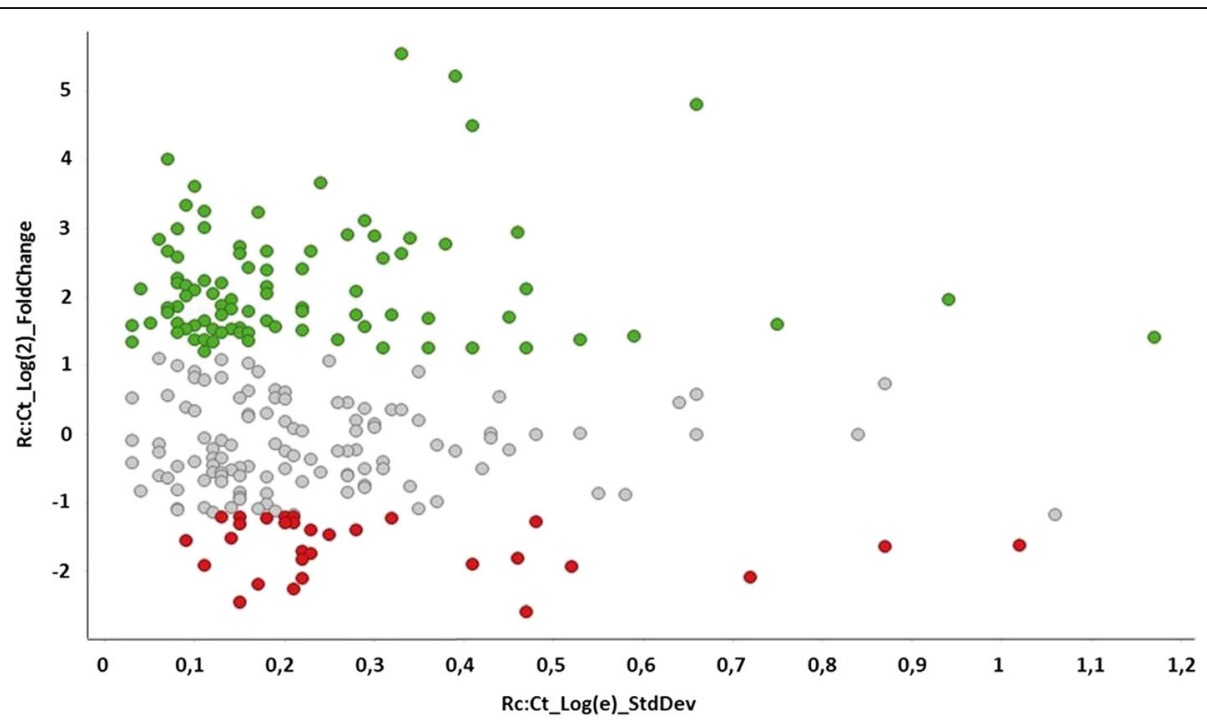

Fig. 3 Volcano Plot show Log(2) Fold Change of the differentially expressed proteins detected by label-free proteomics between the recovered and control condition. Green: Up-regulated proteins; Grey: unchanged proteins; Red: Down-regulated proteins 
Table 2 Proteins differentially produced among the recovered and control condition

\begin{tabular}{|c|c|c|c|c|}
\hline Accession & Description & Score & Fold Change_Log & SecretomeP \\
\hline \multicolumn{5}{|l|}{ Transport } \\
\hline D9Q5H9_CORP1 & Periplasmic binding protein Lacl & 5601,78 & 3,26 & 0.612642 \\
\hline D9Q6G4_CORP1 & Oligopeptide binding protein opp $A^{b}$ & 4120,1 & 3,00 & 0.892226 \\
\hline D9Q4T5_CORP1 & $\mathrm{ABC}$ transporter domain containing ATP & 1264,05 & 2,57 & 0.084974 \\
\hline D9Q7K5_CORP1 & Oligopeptide binding protein opp $\mathrm{A}^{\mathrm{b}}$ & 33697,17 & 2,11 & 0.873687 \\
\hline D9Q5B8_CORP1 & Oligopeptide binding protein opp $A^{b}$ & 852,88 & 1,88 & 0.849217 \\
\hline D9Q6C3_CORP1 & $A B C$ type metal ion transport system permease & 650,43 & 1,59 & 0.078043 \\
\hline D9Q796_CORP1 & Glutamate binding protein GluB & 6254,68 & $-1,46$ & 0.840325 \\
\hline D9Q7W9_CORP1 & Iron(3+)-hydroxamate-binding protein fhuD & 2774,62 & $-1,62$ & 0.824030 \\
\hline \multicolumn{5}{|l|}{ Cell division } \\
\hline D9Q7G1_CORP1 & Septum formation initiator protein & 2071,46 & 1,38 & 0.551153 \\
\hline \multicolumn{5}{|l|}{ Cell adhesion } \\
\hline D9Q5H7_CORP1 & Hypothetical protein & 115906,3 & 1,51 & 0.840443 \\
\hline \multicolumn{5}{|c|}{ DNA synthesis and repair } \\
\hline D9Q7J1_CORP1 & GTP binding protein YchF & 3487,98 & 2,68 & 0.042575 \\
\hline D9Q5F7_CORP1 & Chromosome partitioning protein $\mathrm{ParB}^{\mathrm{b}}$ & 2467,24 & 2,44 & 0.052395 \\
\hline D9Q5G6_CORP1 & DNA polymerase III subunit beta & 1907,74 & 1,80 & 0.071008 \\
\hline D9Q5V6_CORP1 & Nucleoid associated protein ${ }^{c}$ & 68097,59 & 1,59 & 0.070074 \\
\hline \multicolumn{5}{|l|}{ Transcription } \\
\hline D9Q6J8_CORP1 & DNA directed RNA polymerase subunit & 29671,46 & 1,38 & 0.094910 \\
\hline D9Q748_CORP1 & tRNA rRNA methyltransferase & 2467,24 & 1,27 & 0.060356 \\
\hline D9Q8L3_CORP1 & DNA directed RNA polymerase subunit omega & 3784,13 & $-1,21$ & 0.700214 \\
\hline D9Q6D1_CORP1 & DNA directed RNA polymerase subunit beta & 2611,89 & $-1,27$ & 0.067182 \\
\hline D9Q8A5_CORP1 & RNA polymerase-binding protein $\mathrm{RbpA}$ & 10787,51 & $-1,75$ & 0.103548 \\
\hline \multicolumn{5}{|l|}{ Translation } \\
\hline D9Q584_CORP1 & $30 S$ ribosomal protein S6 & 20750,74 & 4,82 & 0.047667 \\
\hline D9Q6E4_CORP1 & Elongation factor $G^{b}$ & 16882,71 & 3,25 & 0.082321 \\
\hline D9Q513_CORP1 & Peptidyl prolyl cis trans isomerase ${ }^{b}$ & 61648,39 & 2,91 & 0.142641 \\
\hline D9Q835_CORP1 & Phenylalanine tRNA ligase beta subunit & 1269,7 & 2,74 & 0.064869 \\
\hline D9Q6L0_CORP1 & $50 S$ ribosomal protein L13 & 5689,37 & 2,64 & 0.101816 \\
\hline D9Q6H2_CORP1 & $50 S$ ribosomal protein $L 5^{b}$ & 3269,32 & 2,12 & 0.076250 \\
\hline D9Q918_CORP1 & Proline tRNA ligase ${ }^{b}$ & 932,79 & 2,12 & 0.072151 \\
\hline D9Q6C0_CORP1 & $50 S$ ribosomal protein $L 10^{b}$ & 27143,51 & 1,86 & 0.031374 \\
\hline D9Q6F6_CORP1 & $50 S$ ribosomal protein $L 23^{b}$ & 6947,79 & 1,85 & 0.060878 \\
\hline D9Q6H1_CORP1 & 50 S ribosomal protein L24 & 27887,33 & 1,75 & 0.078408 \\
\hline F9Y2W9_CORP1 & Hypothetical protein & 3152,39 & 1,75 & 0.591013 \\
\hline D9Q6H6_CORP1 & $30 S$ ribosomal protein $S 8^{c, b}$ & 4941,19 & 1,56 & 0.088407 \\
\hline D9Q6F3_CORP1 & $30 \mathrm{~S}$ ribosomal protein $\mathrm{S} 10^{\mathrm{b}}$ & 25117,55 & 1,54 & 0.048124 \\
\hline D9Q6G2_CORP1 & $50 S$ ribosomal protein L29 & 2467,24 & 1,44 & 0.050948 \\
\hline D9Q401_CORP1 & $50 S$ ribosomal protein $L 27^{b}$ & 2467,24 & 1,38 & 0.081399 \\
\hline D9Q7E8_CORP1 & $50 S$ ribosomal protein L25 & 1358,05 & $-1,28$ & 0.037225 \\
\hline D9Q6H8_CORP1 & $50 S$ ribosomal protein L18 & 8920,94 & $-1,31$ & 0.049024 \\
\hline D9Q754_CORP1 & Homoserine dehydrogenase & 698,17 & $-1,40$ & 0.035138 \\
\hline
\end{tabular}


Table 2 Proteins differentially produced among the recovered and control condition (Continued)

\begin{tabular}{|c|c|c|c|c|}
\hline D9Q6B7_CORP1 & $50 S$ ribosomal protein L1 & 10218.08 & $-1,63$ & 0.633387 \\
\hline D9Q4T4_CORP1 & ATP dependent chaperone protein ClpB & 1883,16 & $-1,80$ & 0.045308 \\
\hline D9Q8N9_CORP1 & Aspartate tRNA ligase & 1004,33 & $-2,18$ & 0.092415 \\
\hline D9Q7S2_CORP1 & Arginine tRNA ligase & 2679,11 & $-2,44$ & 0.051908 \\
\hline \multicolumn{5}{|l|}{ Pathogenesis } \\
\hline D9Q8M7_CORP1 & Metallopeptidase family M24 & 3213,83 & 5,55 & 0.050024 \\
\hline D9Q608_CORP1 & Penicillin binding protein transpeptidase ${ }^{b}$ & 1215,32 & 3,68 & 0.859830 \\
\hline D9Q827_CORP1 & Metallo beta lactamase superfamily protein ${ }^{c}$ & 629,38 & 2,64 & 0.144158 \\
\hline D9Q721_CORP1 & Hypothetical protein ${ }^{c}$ & 112025 & 2,24 & 0.260801 \\
\hline D9Q7K8_CORP1 & Trypsin like serine protease & 35041,27 & 1,96 & 0.648370 \\
\hline D9Q416_CORP1 & ATP dependent Clp protease proteolytic ${ }^{b}$ & 2467,24 & 1,77 & 0.087255 \\
\hline D9Q639_CORP1 & Secreted hydrolase ${ }^{b}$ & 22798,13 & 1,75 & 0.072385 \\
\hline D9Q588_CORP1 & Penicillin binding protein ${ }^{b}$ & 9951,61 & 1,26 & 0.916125 \\
\hline \multicolumn{5}{|l|}{ Energy metabolism } \\
\hline D9Q787_CORP1 & Glucose-6-phosphate isomerase & 1025,89 & 4,50 & 0.058841 \\
\hline D9Q7G0_CORP1 & Enolase $^{b}$ & 53290,95 & 2,18 & 0.068928 \\
\hline D9Q651_CORP1 & Succinate dehydrogenase flavoprotein & 797,48 & 2,02 & 0.159059 \\
\hline D9Q4P2_CORP1 & Acetate kinase $^{b}$ & 10828,79 & 1,96 & 0.063340 \\
\hline D9Q8G5_CORP1 & Aconitate hydratase $^{b}$ & 4250,81 & 1,85 & 0.217637 \\
\hline D9Q4Z7_CORP1 & Phosphoenolpyruvate carboxykinase GTP & 8764,35 & 1,66 & 0.147167 \\
\hline D9Q7X0_CORP1 & 6 phosphofructokinase & 1806,65 & 1,60 & 0.052885 \\
\hline D9Q648_CORP1 & Dihydrolipoyl dehydrogenase & 4110,08 & 1,57 & 0.047180 \\
\hline D9Q7T8_CORP1 & ATP synthase subunit alpha & 2467,24 & 1,49 & 0.070875 \\
\hline D9Q752_CORP1 & Citrate synthase & 6299,21 & $-1,21$ & 0.116042 \\
\hline D9Q895_CORP1 & 6-Phosphogluconate dehydrogenase & 4246,26 & $-1,89$ & 0.050906 \\
\hline \multicolumn{5}{|l|}{ Lipid metabolism } \\
\hline D9Q520_CORP1 & Glycerophosphoryl diester phosphodieste ${ }^{c}$ & 2494,25 & 4,03 & 0.802154 \\
\hline D9Q718_CORP1 & Methylmalonyl CoA carboxyltransferase $1^{\mathrm{b}}$ & 2467,24 & 2,16 & 0.049504 \\
\hline \multicolumn{5}{|c|}{ Amino acid metabolism } \\
\hline D9Q5X8_CORP1 & Aspartokinase $^{b}$ & 1944,81 & 2,86 & 0.043575 \\
\hline D9Q4C2_CORP1 & Succinyl CoA Coenzyme A transferase & 10894,63 & 1,63 & 0.061344 \\
\hline D9Q3L8_CORP1 & Glutamine synthetase & 320,71 & $-1,23$ & 0.263700 \\
\hline D9Q8H7_CORP1 & Cysteine desulfurase & 1689,36 & $-1,70$ & 0.067087 \\
\hline \multicolumn{5}{|l|}{ Stress response } \\
\hline D9Q929_CORP1 & Mycothione glutathione reductase & 490,36 & 2,67 & 0.085017 \\
\hline D9Q5T5_CORP1 & 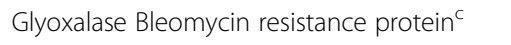 & 8420,32 & 2,21 & 0.226764 \\
\hline D9Q424_CORP1 & DSBA oxidoreductase & 12179,8 & 2,09 & 0.061566 \\
\hline D9Q566_CORP1 & Universal stress protein $A^{b}$ & 2498,69 & 1,70 & 0.034684 \\
\hline D9Q4P4_CORP1 & Ferredoxin ferredoxin NADP reductase ${ }^{b}$ & 1086,71 & 1,69 & 0.083585 \\
\hline D9Q824_CORP1 & Stress related protein ${ }^{b}$ & 2467,24 & 1,54 & 0.035291 \\
\hline D9Q692_CORP1 & Thiol disulfide isomerase thioredoxin & 3721,88 & $-2,25$ & 0.438415 \\
\hline \multicolumn{5}{|c|}{ Metabolism of nucleotides and nucleic acids } \\
\hline D9Q4Y6_CORP1 & Deoxycytidine triphosphate deaminase & 887,26 & 2,39 & 0.216897 \\
\hline
\end{tabular}


Table 2 Proteins differentially produced among the recovered and control condition (Continued)

\begin{tabular}{|c|c|c|c|c|}
\hline & & & \\
\hline D9Q6J1_CORP1 & Adenylate kinase & 15629,86 & 2,21 & 0.059568 \\
\hline D9Q8L4_CORP1 & Guanylate kinase & 2467,24 & 1,34 & 0.050095 \\
\hline D9Q6T2_CORP1 & Ribokinase & 890,09 & $-1,23$ & 0.032324 \\
\hline D9Q4E9_CORP1 & Adenylosuccinate lyase & 1441,99 & $-1,54$ & 0.035597 \\
\hline D9Q6P0_CORP1 & D methionine binding lipoprotein metQ & 11519,67 & $-1,93$ & 0.817217 \\
\hline \multicolumn{5}{|c|}{ Carbohydrate metabolism } \\
\hline D9Q8V2_CORP1 & UDP glucose 4 epimerase ${ }^{b}$ & 2001,76 & 3,13 & 0.094403 \\
\hline D9Q6V6_CORP1 & Phosphomannomutase ManB & 1730,63 & 2,05 & 0.053146 \\
\hline D9Q659_CORP1 & Formate acetyltransferase & 5456,95 & 1,54 & 0.539548 \\
\hline D9Q423_CORP1 & Ribose-5-phosphate isomerase B & 2467,24 & 1,38 & 0.064467 \\
\hline D9Q6V1_CORP1 & Mannose-1-phosphate guanylyltransferase & 1612,45 & $-1,21$ & 0.068085 \\
\hline \multicolumn{5}{|l|}{ Nitrogen metabolism } \\
\hline D9Q4Q8_CORP1 & Cytochrome c nitrate reductase small & 1118,33 & 2,68 & 0.901856 \\
\hline \multicolumn{5}{|l|}{ Unknow function } \\
\hline D9Q6T0_CORP1 & Hypothetical protein & 2277,6 & 3,62 & 0.050552 \\
\hline D9Q4R2_CORP1 & Hypothetical protein & 442,07 & 3,35 & 0.866986 \\
\hline D9Q6N1_CORP1 & Hypothetical protein & 561,84 & 3,02 & 0.062141 \\
\hline D9Q8Q4_CORP1 & Hypothetical protein ${ }^{c}$ & 72711,5 & 2,96 & 0.974016 \\
\hline D9Q832_CORP1 & Hypothetical protein & 1774,59 & 2,90 & 0.752478 \\
\hline D9Q3S8_CORP1 & Hypothetical protein $^{d}$ & 837,6 & 2,78 & 0.231421 \\
\hline D9Q7M9_CORP1 & Hypothetical protein & 3246,28 & 2,60 & 0.147602 \\
\hline D9Q716_CORP1 & Hypothetical protein & 3751,96 & 2,42 & 0.707595 \\
\hline D9Q739_CORP1 & Hypothetical protein & 2845,77 & 2,28 & 0.836229 \\
\hline D9Q4C5_CORP1 & Hypothetical protein & 1339,3 & 1,83 & 0.023133 \\
\hline D9Q5C3_CORP1 & Hypothetical protein & 111234,6 & 1,49 & 0.946918 \\
\hline D9Q700_CORP1 & Hypothetical protein & 2467,24 & 1,49 & 0.072810 \\
\hline D9Q657_CORP1 & Hypothetical protein & 1172,66 & 1,41 & 0.830926 \\
\hline D9Q6F2_CORP1 & Hypothetical protein & 2467,24 & 1,34 & 0.061860 \\
\hline D9Q7X5_CORP1 & Hypothetical protein & 38716,45 & $-1,21$ & 0.825761 \\
\hline D9Q4T9_CORP1 & Hypothetical protein & 553,76 & $-1,28$ & 0.934591 \\
\hline D9Q6R6_CORP1 & Hypothetical protein & 1457,62 & $-1,40$ & 0.206908 \\
\hline D9Q890_CORP1 & Hypothetical protein & 1948,52 & $-1,51$ & 0.847549 \\
\hline D9Q6M6_CORP1 & Hypothetical protein ${ }^{c}$ & 1935,68 & $-1,90$ & 0.823541 \\
\hline \multicolumn{5}{|l|}{ Others } \\
\hline D9Q613_CORP1 & Maltotriose binding protein & 5210,9 & 5,22 & 0.864851 \\
\hline D9Q4A3_CORP1 & DsbG protein & 3101,13 & 2,06 & 0.814366 \\
\hline D9Q6N9_CORP1 & D methionine binding lipoprotein metQ & 2665,58 & 1,79 & 0.764416 \\
\hline D9Q732_CORP1 & Carbonic anhydrase ${ }^{\mathrm{b}}$ & 689,15 & 1,66 & 0.130559 \\
\hline D9Q6W6_CORP1 & Lipoprotein LpqB & 1484,31 & 1,63 & 0.670057 \\
\hline D9Q556_CORP1 & LSR2 like protein & 2714,21 & 1,49 & 0.096802 \\
\hline D9Q5Q0_CORP1 & UPF0145 protein & 2467,24 & 1,37 & 0.025009 \\
\hline D9Q7W0_CORP1 & Hypothetical protein & 2467,24 & 1,26 & 0.039678 \\
\hline D9Q701_CORP1 & UPF0182 protein & 1682,98 & 1,26 & 0.869411 \\
\hline D9Q8A3_CORP1 & Protein ycel ${ }^{\mathrm{b}}$ & 16885,01 & 1,21 & 0.901679 \\
\hline
\end{tabular}


Table 2 Proteins differentially produced among the recovered and control condition (Continued)

\begin{tabular}{|c|c|c|c|c|}
\hline D9Q5X4_CORP1 & Serine aspartate repeat containing protein & 528,36 & $-1,82$ & 0.892317 \\
\hline D9Q826_CORP1 & DoxX family protein & 697,26 & $-2,08$ & 0.614317 \\
\hline D9Q7W3_CORP1 & Mycothiol acetyltransferase & 947,33 & $-2,11$ & 0.214833 \\
\hline D9Q407_CORP1 & Ornithine cyclodeaminase & 2566,18 & $-2,58$ & 0.048247 \\
\hline
\end{tabular}

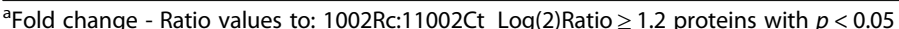

${ }^{\mathrm{b}}$ Identified in an isolated of $C$. pseudotuberculosis from ovine lymph nodes [Rees et al. [12]

'Induced in 1002_ovis during to stress nitrosative [Pacheco et al. [57], Silva et al. [58]

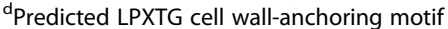

Table 3 List of proteins identified in the exclusive proteome of recovered-condition

\begin{tabular}{|c|c|c|c|c|}
\hline Accession & Description & Score & Biological process & SecretomeP \\
\hline D9Q869_CORP1 & Esterase $^{a}$ & 251.44 & Others & 0.862935 \\
\hline D9Q575_CORP1 & Cation transport protein & 1961.29 & Transport & 0.062276 \\
\hline D9Q5N5_CORP1 & Uncharacterized iron regulated membrane ${ }^{a}$ & 46.77 & Transport & 0.855681 \\
\hline D9Q3T9_CORP1 & Pyridoxamine kinase & 216.2 & Cofactor metabolism & 0.083313 \\
\hline D9Q751_CORP1 & Phosphoserine aminotransferase & 639.64 & Amino acid metabolism & 0.151778 \\
\hline D9Q537_CORP1 & LytR family transcriptional regulator ${ }^{a}$ & 375.8 & Transcription & 0.766483 \\
\hline D9Q7F2_CORP1 & Multicopper oxidase & 74.63 & Stress response & 0.278840 \\
\hline D9Q525_CORP1 & $A B C$ transporter substrate binding lipoprotein & 283.38 & Transport & 0.452814 \\
\hline D9Q6P2_CORP1 & Manganese $A B C$ transporter substrate binding ${ }^{a}$ & 236.6 & Transport & 0.774461 \\
\hline D9Q4C8_CORP1 & Phosphate $A B C$ transporter phosphate binding ${ }^{a}$ & 125.4 & Transport & 0.840195 \\
\hline D9Q4L0_CORP1 & D alanyl D alanine carboxypeptidase OS & 426.74 & Others & 0.232261 \\
\hline D9Q4T7_CORP1 & Hyphotetical protein & 157.52 & Unknow function & 0.349026 \\
\hline D9Q5A9_CORP1 & Hyphotetical protein & 218.02 & Unknow function & 0.907333 \\
\hline D9Q476_CORP1 & Hyphotetical protein & 510.32 & Unknow function & 0.066368 \\
\hline D9Q5B3_CORP1 & Glucosamine-6-phosphate deaminase ${ }^{b}$ & 524,55 & Carbohydrate metabolism & 0.079507 \\
\hline D9Q474_CORP1 & Glutamate racemase & 343,98 & Cell wall organization & 0.040278 \\
\hline D9Q7N5_CORP1 & O-methyltransferase & 619,11 & DNA process & 0.032455 \\
\hline D9Q5N3_CORP1 & Gamma type carbonic anhydratase & 577,75 & Others & 0.035357 \\
\hline D9Q4X0_CORP1 & Urease accessory protein UreD & 333,12 & Others & 0.055896 \\
\hline D9Q5J0_CORP1 & Phospholipase $D^{b}$ & 40,25 & Pathogenesis & 0.409585 \\
\hline D9Q8S8_CORP1 & Copper resistance protein CopC & 4315,26 & Stress response & 0.964015 \\
\hline D9Q493_CORP1 & Glutaredoxin like protein $\mathrm{nrdH}$ & 725,98 & Stress response & 0.033036 \\
\hline D9Q6Y6_CORP1 & ATP dependent RNA helicase rhIE & 1438,25 & Transcription & 0.060627 \\
\hline D9Q4M0_CORP1 & Cell wall channel & 4008,59 & Transport & 0.025882 \\
\hline D9Q4V1_CORP1 & CP40 & 558,79 & Pathogenesis & 0.926013 \\
\hline D9Q6V9_CORP1 & Hyphotetical protein & 1278,45 & Unknow function & 0.953803 \\
\hline D9Q6A8_CORP1 & Hyphotetical protein & 326,47 & Unknow function & 0.918886 \\
\hline D9Q485_CORP1 & Hyphotetical protein & 2795,11 & Unknow function & 0.890081 \\
\hline D9Q4N2_CORP1 & Hypothetical protein ${ }^{a}$ & 708,75 & Unknow function & 0.857050 \\
\hline D9Q559_CORP1 & Hypothetical protein ${ }^{a}$ & 475,62 & Unknow function & 0.472378 \\
\hline D9Q4L8_CORP1 & Hyphotetical protein & 5324,08 & Unknow function & 0.038893 \\
\hline D9Q4T0_CORP1 & Hyphotetical protein & 732,37 & Unknow function & 0.037132 \\
\hline
\end{tabular}

anduced in 1002_ovis during to stress nitrosative [Pacheco et al. [57], Silva et al. [58]

${ }^{\mathrm{b}}$ Identified in an isolated of C. pseudotuberculosis from ovine lymph nodes [Rees et al. [12] 


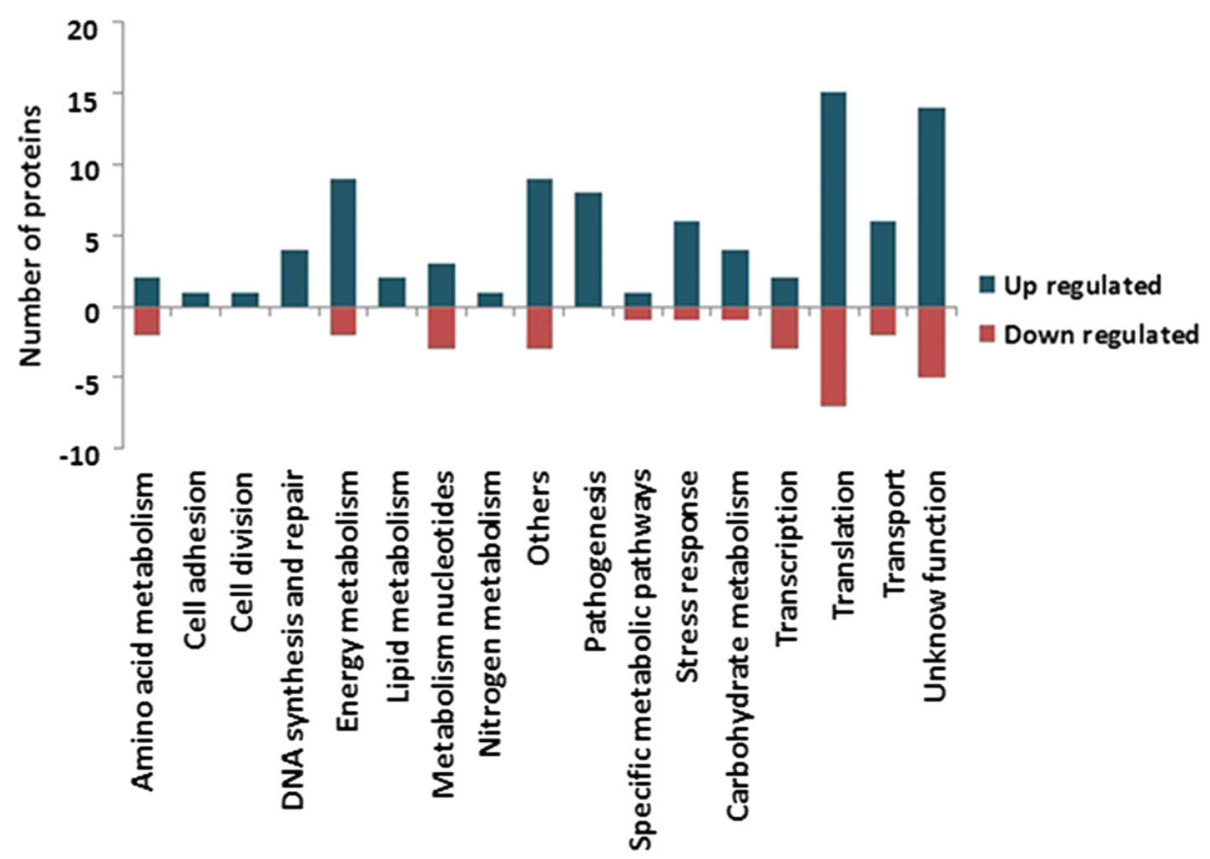

Fig. 4 Biological processes differentially regulated in 1002_ovis after passage in mice. Analysis of the differentially expressed proteins grouped into biological processes for strain 1002_ovis after passage in mice

expression profile of the strain, especially for effectors related to bacterial virulence. This phenomenon has also been reported in other pathogens such as Mycobacterium bovis, Helicobacter pylori, S. aureus, and L. monocytogenes. In vitro passages of these bacteria on culture medium altered both bacterial physiology and virulence profile [41-44]. However, we showed that the bacterial passage process in a murine model changed the virulence potential of strain 1002_ovis. Previous reports on experimental serial passages showed that pathogens such as $H$. pylori, Escherichia coli, Xenorhabdus nematophila, Arcobacter butzleri, and Salmonella enterica also exhibited altered virulence profiles after in vivo passage in a host, which helped identifying factors that contribute to infectious process [14-19]. Thus, as observed in these pathogens, the recovered condition also showed increased capacity to persist into host, when compared with control condition. The altered physiology and virulence status observed in 1002_ovis is supported by our proteomic analyses, where several proteins involved in processes favoring infection and host adaptation were differentially expressed after passage in mice.

Although our study focused on the C. pseudotuberculosis extracellular proteins, cytoplasmic proteins were also detected in the proteomic analyses. The presence of cytoplasmic proteins in the extracellular fraction is reported in several other proteomic studies [8-10, 12, 45]. It may be partially due to cell lysis and thus, be considered artifacts. However, cytoplasmic proteins in the culture supernatant may act as moonlighting proteins and be exported via a non-classical secretion pathway [30, 46]. The moonlighting proteins are described both Grampositive and Gram-negative bacteria, and can be detected in different subcellular locations (cytoplasm, membrane, cell surface, and extracellular environment) and exhibit distinct functional behavior depending on the host cell type [46, 47]. Interestingly, some proteins, such as Chromosome partitioning protein ParB, Phosphoenolpyruvate carboxykinase GTP, Methylmalonyl CoA carboxyltransferase $12 \mathrm{~S}$ subunit, Acetate kinase, and Enolase, induced in the Rc supernatants were identified only in the membrane shaving of C. pseudotuberculosis harvested directly from ovine lymph nodes [12].

The passage process in mice was also able to induce other proteins identified in Rc supernatants, and which contribute to the adhesion process. Proteins with an LPTXG domain, which characterizes the cell-wall anchored proteins, were identified and included monomers of membrane pilus. This latter class of proteins is described in pathogenic Corynebacterium species and may contribute especially in the process of cellular adhesion [48]. In Campylobacter jejuni, serial passages in mice induce the expression of invasiveness and increase the capacity of cell invasion [13]. Components of the Opp system were induced by the passage process, too. The Opp system facilitates the uptake of extracellular peptides, which are further used as carbon and nitrogen sources for bacterial nutrition [49]. Proteins that comprise the Opp system also were induced in a field isolated of C. pseudotuberculosis biovar ovis, when 
compared with the strain C231_ovis a laboratory reference strain [12, 50]. In the pathogen Mycobacterium avium the OppA gene was highly expressed during the infection in a mouse model [51]. We have identified known secreted virulence factors as $\mathrm{CP} 40$ serine protease, which previously shown to be necessary for C. pseudotuberculosis virulence potential and to induce an immune response [52, 53].

An important factor that precedes the chronic stage of infection by $C$. pseudotuberculosis is the capacity of this pathogen to disseminate within the host, which consequently favors the establishment of the disease [3]. In $C$. pseudotuberculosis, this process is mediated by the action of PLD exotoxin, a major virulence factor of this pathogen $[54,55]$ that catalyzes the dissociation of sphingomyelin and increases vascular permeability, which contributes to the dissemination process of $C$. pseudotuberculosis in the host. Here, PLD was only detected in the proteome of the Rc condition. This result is noteworthy because, a previous proteomic study performed by our research group, PLD was not identified in the extracellular proteome of 1002_ovis [8-10]. McKean et al. [5] showed that pld expression is expressed by different environmental factors, thus during the infection and recuperation process 1002_ovis was exposed to different environmental and stimulus, which may have affected the pld expression. A study showed that a pld mutant strain is indeed unable to disseminate and yields reduced virulence [55]. Here, we observed the presence of caseous lesions in different organs only at the end of experimental infection, only in the group of mice infected with the Rc condition. Altogether, the observations suggest that the expression of PLD can be modified by the passage in the host and can thus change the virulence potential of 1002_ovis.

Another attribute of PLD is its capacity to alter the viability of macrophage cells during the infection [5]. However, before promoting macrophages lysis, $C$. pseudotuberculosis has to be able to resist the hostile environment inside macrophages mainly against reactive oxygen species (ROS) and reactive nitrogen species (RNS). Thus, the induction of proteins involved in detoxification processes in Rc could be contributed for its resistance against ROS and RNS. The inductions of proteins related to oxidative stress also were observed in Shigella flexneri, after recuperation process in an in vivo infection model. We detected the mycothione glutathione reductase, a component of the mycothiol system, which is present in Mycobacterium and Rhodococcus genera. This system is used as an alternative mechanism of disulphide reduction and contributes to the cytosolic redox homeostasis and the resistance to ROS [35]. Glutaredoxin-like protein, $\mathrm{NrdH}$, which plays an important role in the resistance to ROS, and is present in C. glutamicum [34] and $M$. tuberculosis [56] was also detected.
On the other hand, some proteins like dihydroxybiphenyl dioxygenase, Metallo beta lactamase superfamily protein, Formamidopyrimidine DNA glycosylase, MerR family transcriptional regulator, which were induced by 1002_ovis during the exposition to nitric oxide $[57,58]$ were also found induced in this study in the recovered condition. These proteins are related to different processes of resistance to nitrosative stress, DNA repair, antibiotic resistance, and transcription, these results show a set of proteins involved in the adaptation process of 1002_ovis to nitric oxide, which could contribute to the pathogenic process of this pathogen. Another type of defense of the host immune system against bacterial infection is the utilization of copper [59]. Here, $\mathrm{CopC}$, a protein related to copper resistance, was detected in recovered 1002_ovis. In M. tuberculosis, proteins involved in copper resistance are essential to virulence $[60,61]$. Thus, the association of this factor related to an antioxidant system with PLD could promote an effective pathway of defense against the action of the innate immune system and consequently contributes to virulence process of $C$. pseudotuberculosis.

\section{Conclusion}

In conclusion, the virulence potential and proteomic profiles of strain 1002_ovis undergo dramatic changes after recovery from experimentally infected mice. The proteomic screening outlined, after the serial passage in murine model showed a set of proteins that were induced in the recovered condition. Into this group were detected known secreted virulence factors, as well as some proteins which could contribute in its virulence. Therefore, more study is necessary to show the true role of these proteins in the virulence of $C$. pseudotuberculosis. Altogether, our results demonstrate that in vitro passages alter the expression of C. pseudotuberculosis exoproteome leading to a reduced virulence and that a single passage in vivo, in a murine model, can induce significant changes in the C. pseudotuberculosis extracellular proteome, contributing to the increase in virulence of this pathogen.

\section{Additional files}

Additional file 1: Table S1. Complete list of proteins differentially produced between the recovered and control condition of strain 1002_ovis. (XLSX $44 \mathrm{~kb})$

Additional file 2: Table S2. List of proteins identified in the exclusive proteome of control condition. (XLSX $12 \mathrm{~kb}$ )

Additional file 3: Table S3. Total list of peptide and proteins identified by LC-MS ${ }^{E}$. (XLSX 3 mb)

Additional file 4: Table S4. Proteins identified in the recovered condition detected in pathogenicity island. (XLSX $10 \mathrm{~kb}$ )

\section{Acknowledgements}

The authors would like to thank to Pará State Genomics and Proteomics Network and Waters Corporation, Brazil. 


\section{Funding}

The work was supported by the Brazilian Federal Agency for the Support and Evaluation of Graduate Education (CAPES), Pará Research Foundation (FAPESPA), Minas Gerais Research Foundation (FAPEMIG) and the National Council for Scientific and Technological Development (CNPq). Yves Le Loir is the recipient of a PVE grant (71/2013) from Programa Ciências sem Fronteiras.

\section{Availability of data and materials}

The datasets supporting the results of this article were then concatenated into a *xIsx file at peptide and protein level to fulfill the requirements and is available at supplemental material including sequence coverage and a number of identified peptides for each protein sequence identified. It also includes the native peptide information. In addition other data are included within the article.

\section{Authors' contributions}

VA, WMS, and FAD designed the experiments. WMS and FAD performed in vivo experiments. WMS, TLPC, and NS performed microbiological analyses and sample preparation for proteomic analysis. GHMFS and WMS conducted the proteomic analysis. WMS and SCS performed bioinformatics analysis of the data. YLL, AM, and HF contributed substantially to data interpretation and revisions. VA, AS, and YLL participated in all steps of the project as coordinators, and critically reviewed the manuscript. All authors read and approved the final manuscript.

\section{Competing interests}

The authors declare that they have no competing interests.

\section{Consent for publication}

Not applicable.

\section{Ethics approva}

All animals used in this study were provided by the Animal Care Facility of the Biological Sciences Institute from the Federal University of Minas Gerais and were handled by the guidelines of the UFMG Ethics Committee on Animal Testing (Permit Number: CETEA 103/2011).

\section{Author details}

'Departamento de Biologia Geral, Instituto de Ciências Biológicas, Universidade Federal de Minas Gerais, Belo Horizonte, Minas Gerais, Brazil. ${ }^{2}$ Instituto de Ciências Biológicas, Universidade Federal do Pará, Guamá, Belém, Pará, Brazil. ${ }^{3}$ Waters Corporation, Waters Technologies Brazil, MS Applications Laboratory, Alphaville, São Paulo, Brazil. ${ }^{4}$ INRA, UMR1253 STLO, 35042 Rennes, France. ${ }^{5}$ Agrocampus Ouest, UMR1253 STLO, 35042 Rennes, France. ${ }^{6}$ Aquacen, Escola de Veterinária, Universidade Federal de Minas Gerais, Belo Horizonte, Brazil.

Received: 15 January 2016 Accepted: 4 January 2017

Published online: 22 March 2017

\section{References}

1. Dorella FA, Pacheco LG, Oliveira SC, Miyoshi A, Azevedo V. Corynebacterium pseudotuberculosis: microbiology, biochemical properties, pathogenesis and molecular studies of virulence. Vet Res. 2006:37:201-18.

2. Paton MW, Walker SB, Rose IR, Watt GF. Prevalence of caseous lymphadenitis and usage of caseous lymphadenitis vaccines in sheep flocks. Aust Vet J. 2003;81:91-5

3. Batey RG. Pathogenesis of caseous lymphadenitis in sheep and goats. Aust Vet J. 1986;63:269-72.

4. Pépin M, Pittet JC, Olivier M, Gohin I. Cellular composition of Corynebacterium pseudotuberculosis pyogranulomas in sheep. J Leukoc Biol. 1994;56:666-70.

5. McKean SC, Davies JK, Moore RJ. Expression of phospholipase D, the major virulence factor of Corynebacterium pseudotuberculosis, is regulated by multiple environmental factors and plays a role in macrophage death Microbiology. 2007;153:2203-11.

6. Green ER, Mecsas J. Bacterial Secretion Systems - An overview. Microbio Spectr. 2016:4:1. Hilbi H, Haas A. Secretive bacterial pathogens and the secretory pathway. Traffic. 2012; 13:1187-1197.

7. Dorella FA, Estevam EM, Pacheco LG, Guimarães CT, Lana UG, Gomes EA, et al. In vivo insertional mutagenesis in Corynebacterium pseudotuberculosis: an efficient means to identify DNA sequences encoding exported proteins. Appl Environ Microbiol. 2006;72:7368-72.

8. Pacheco LG, Slade SE, Seyffert N, Santos AR, Castro TL, Silva WM, et al. A combined approach for comparative exoproteome analysis of Corynebacterium pseudotuberculosis. BMC Microbiol. 2011;17:12.

9. Silva WM, Seyffert N, Santos AV, Castro TL, Pacheco LG, Santos AR, et al. Identification of 11 new exoproteins in Corynebacterium pseudotuberculosis by comparative analysis of the exoproteome. Microb Pathog. 2013;16:37-42.

10. Silva WM, Seyffert N, Ciprandi A, Santos AV, Castro TL, Pacheco LG, et al. Differential Exoproteome analysis of two Corynebacterium pseudotuberculosis biovar ovis strains isolated from goat (1002) and sheep. Curr Microbiol. 2013;67:460-5.

11. Seyffert N, Silva RF, Jardin J, Silva WM, Castro TL, Tartaglia NR, et al. Serological proteome analysis of Corynebacterium pseudotuberculosis isolated from different hosts reveals novel candidates for prophylactics to control caseous lymphadenitis. Vet Microbiol. 2014;174:255-60.

12. Rees MA, Kleifeld O, Crellin PK, Ho B, Stinear TP, Smith Al, Coppel RL. Proteomic Characterization of a Natural Host-Pathogen Interaction: Repertoire of in vivo Expressed Bacterial and Host Surface-Associated Proteins. J Proteome Res. 2015;2:120-32.

13. Fernández $\mathrm{H}$, Vivanco $\mathrm{T}$, Eller $\mathrm{G}$. Expression of invasiveness of Campylobacter jejuni ssp. jejuni after serial intraperitoneal passages in mice. J Vet Med B Infect Dis Vet Public Health. 2000;47:635-9.

14. Bleich A, Kohn I, Glage S, Beil W, Wagner S, Mahler M. Multiple in vivo passages enhance the ability of clinical Helicobacter pylori isolate to colonize the stomach of Mongolian gerbils and to induce gastritis. Lab Anim. 2005:39:221-9.

15. Chapuis É, Pagès S, Emelianoff V, Givauda A, Ferdy JB. Virulence and pathogen multiplication: a serial passage experiment in the hypervirulent bacterial insectpathogen Xenorhabdus nematophila. PLoS One. 2011;31:e15872.

16. Fernandez-Brando RJ, Miliwebsky E, Mejías MP, Baschkier A, Panek CA Abrey-Recalde MJ, et al. Shiga toxin-producing Escherichia coli O157: H7 shows an increased pathogenicity in mice after the passage through the gastrointestinal tract of the same host. J Med Microbiol. 2012;61:852-9.

17. Fernández H, Flores SP, Villanueva M, Medina G, Carrizo M. Enhancing adherence of Arcobacter butzleri after serial intraperitoneal passages in mice. Rev Argent Microbiol. 2013:45:75-9.

18. Koskiniemi S, Gibbons HS, Sandegren L, Anwar N, Ouellette G, Broomall S, et al. Pathoadaptive mutations in Salmonella enterica isolated after serial passage in mice. PLoS One. 2013;25:e70147.

19. Liu X, Lu L, Liu X, Pan C, Feng E, Wang D, Zhu L, Wang H. Comparative proteomics of Shigella flexneri 2a strain using a rabbit ileal loop model reveals key proteins for bacterial adaptation in host niches. Int J Infect Dis. 2015:40:28-33.

20. Moraes PM, Seyffert N, Silva WM, Castro TL, Silva RF, Lima DD, et al. Characterization of the Opp peptide transporter of Corynebacterium pseudotuberculosis and its role in virulence and pathogenicity. Biomed Res Int. 2014;2014:489782.

21. Ribeiro D, Rocha FS, Leite KM, Soares SC, Silva A, Portela RW, et al. An iron acquisition-deficient mutant of Corynebacterium pseudotuberculosis efficiently protects mice against challenge. Vet Res. 2014;45:28.

22. Moura-Costa LF, Paule BJA, Freire SM, Nascimento I, Schaer R, Regis LF, et al. Chemically defined synthetic medium for Corynebacterium pseudotuberculosis culture. Rev Bras Saúde Prod An. 2002;3:1-9.

23. Paule BJ, Meyer R, Moura-Costa LF, Bahia RC, Carminati R, Regis LF, et al, Three-phase partitioning as an efficient method for extraction/ concentration of immunoreactive excreted-secreted proteins of Corynebacterium pseudotuberculosis. Protein Expr Purif. 2004;34:311-166.

24. Bradford MM. A rapid and sensitive method for the quantitation of microgram quantities of protein utilizing the principle of protein-dye binding. Anal Biochem. 1976;72:248-54

25. Silva JC, Gorenstein MV, Li GZ, Vissers JP, Geromanos SJ. Absolute quantification of proteins by LCMSE: a virtue of parallel MS acquisition. Mol Cell Proteomics. 2006:5:144-56.

26. Gilar M, Olivova P, Daly AE, Gebler JC. Two-dimensional separation of peptides using RP-RP-HPLC system with different $\mathrm{pH}$ in first and second separation dimensions. J Sep Sci. 2005:8:1694-703.

27. Geromanos SJ, Vissers JP, Silva JC, Dorschel CA, Li GZ, Gorenstein MV, et al. The detection, correlation, and comparison of peptide precursor and product ions from data independent LC-MS with data dependant LC-MS/ MS. Proteomics. 2009;9:1683-95.

28. Li GZ, Vissers JP, Silva JC, Golick D, Gorenstein MV, Geromanos SJ. Database searching and accounting of multiplexed precursor and product ion spectra 
from the data independent analysis of simple and complex peptide mixtures. Proteomics. 2009;9:1696-719.

29. Curty N, Kubitschek-Barreira PH, Neves GW, Gomes D, Pizzatti L, Abdelhay E. Discovering the infectome of human endothelial cells challenged with Aspergillus fumigatus applying a mass spectrometry label-free approach. J Proteomics. 2014:31:126-40.

30. Bendtsen JD, Kiemer L, Fausboll A, Brunak S. Non-classical protein secretion in bacteria. BMC Microbiol. 2005;5:58.

31. Soares SC, Abreu VA, Ramos RT, Cerdeira L, Silva A, Baumbach J. PIPS: pathogenicity island prediction software. PLoS One. 2012;7:e30848.

32. Conesa A, Gotz S, García-Gómez JM, Terol J, Talón M, Robles M. Blast2GO: a universal tool for annotation, visualization and analysis in functional genomics research. Bioinformatics. 2005;15:3674-6.

33. Levin Y, Hradetzky E, Bahn S. Quantification of proteins using dataindependent analysis (MSE) in simple and complex samples: a systematic evaluation. Proteomics. 2011;11:3273-87.

34. Si MR, Zhang L, Yang ZF, Xu YX, Liu YB, Jiang CY, et al. NrdH Redoxin enhances resistance to multiple oxidative stresses by acting as a peroxidase cofactor in Corynebacterium glutamicum. Appl Environ Microbiol. 2014;80:1750-62.

35. Newton GL, Buchmeier N, Fahey RC. Biosynthesis and functions of mycothiol, the unique protective thiol of Actinobacteria. Microbiol Mol Biol Rev. 2008;72:471-94

36. Frees D, Qazi SN, Hill PJ, Ingmer H. Alternative roles of ClpX and ClpP in Staphylococcus aureus stress tolerance and virulence. Mol Microbiol. 2013;48:1565-78.

37. Gaillot O, Pellegrini E, Bregenholt S, Nair S, Berche P. The ClpP serine protease is essential for the intracellular parasitism and virulence of Listeria monocytogenes. Mol Microbiol. 2000;35:1286-94.

38. Ribeiro OC, Silva JAH, Oliveira SC, Meyer R, Fernandes GB. Preliminary results on a living vaccine against caseous lymphadenitis. Pesq Agrop Brasileira. 1991;26:461-5.

39. Meyer R, Carminati R, Cerqueira RB, Vale V, Viegas S, Martinez T. Evaluation of the goats humoral immune response induced by the Corynebacterium pseudotuberculosis lyophilized live vaccine. Rev Cienc Méd Biol. 2002;1:42-8.

40. Ruiz JC, D'Afonseca V, Silva A, Ali A, Pinto AC, Santos AR. Evidence for reductive genome evolution and lateral acquisition of virulence functions in two Corynebacterium pseudotuberculosis strains. PLoS One. 2011;18:e18551.

41. Nascimento IP, Leite LC. The effect of passaging in liquid media and storage on Mycobacterium bovis-BCG growth capacity and infectivity. FEMS Microbiol Lett. 2005;1:81-6.

42. Hopkins RJ, Morris Jr JG, Papadimitriou JC, Drachenberg C, Smoot DT, James SP, Panigrahi P. Loss of Helicobacter pylori hemagglutination with serial laboratory passage and correlation of hemagglutination with gastric epithelial cell adherence. Pathobiology. 1996;64:247-54.

43. Somerville GA, Beres SB, Fitzgerald JR, DeLeo FR, Cole RL, Hoff JS, Musser JM. In vitro Serial Passage of Staphylococcus aureus: Changes in Physiology, Virulence Factor Production, and agr Nucleotide Sequence. J Bacteriol. 2002;184:1430-7.

44. Asakura H, Kawamoto K, Okada Y, Kasuga F, Makino S, Yamamoto S, lgimi S. Intra host passage alters SigB-dependent acid resistance and host cellassociated kinetics of Listeria monocytogenes. Infect Genet Evol. 2012;12:94-101.

45. Muthukrishnan G, Quinn GA, Lamers RP, Diaz C, Cole AL, Chen S, Cole AM. Exoproteome of Staphylococcus aureus reveals putative determinants of nasal carriage. J Proteome Res. 2011;1:2064-78.

46. Henderson B, Martin A. Bacterial virulence in the moonlight: multitasking bacterial moonlighting proteins are virulence determinants in infectious disease. Infect Immun. 2011;79:3476-91.

47. Peng Z, Krey V, Wei H, Tan Q, Vogelmann R, Ehrmann MA, Vogel RF. Impact of actin on adhesion and translocation of Enterococcus faecalis. Arch Microbiol. 2014;196:109-17.

48. Rogers EA, Das A, Ton-That H. Adhesion by pathogenic corynebacteria. Adv Exp Med Biol. 2011;715:91-103.

49. Lazazzera BA, Solomon J, Grossman AD. An exported peptide functions intracellularly to contribute to cell density signaling in B. subtilis. Cell. 1997; 13:917-25.

50. Rees MA, Stinear TP, Goode RJ, Coppel RL, Smith Al, Kleifeld O. Changes in protein abundance are observed in bacterial isolates from a natural host. Front Cell Infect Microbiol. 2015;14(5):71.

51. Danelishvili L, Stang B, Bermudez LE. Identification of Mycobacterium avium genes expressed during in vivo infection and the role of the oligopeptide transporter OppA in virulence. Microb Pathog. 2014;76:67-76.
52. Wilson MJ, Brandon MR, Walker J. Molecular and biochemical characterization of a protective 40-kilodalton antigen from Corynebacterium pseudotuberculosis. Infect Immun. 1995;63:206-11.

53. Silva JW, Droppa-Almeida D, Borsuk S, Azevedo V, Portela RW, Miyoshi A, et al. Corynebacterium pseudotuberculosis cp09 mutant and cp40 recombinant protein partially protect mice against caseous lymphadenitis. BMC Vet Res. 2014;20(10):965.

54. Hodgson AL, Tachedjian M, Corner LA, Radford AJ. Protection of sheep against caseous lymphadenitis by use of a single oral dose of live recombinant Corynebacterium pseudotuberculosis. Infect Immun. 1994;62:5275-80.

55. McNamara PJ, Bradley GA, Songer JG. Targeted mutagenesis of the phospholipase D gene results in decreased virulence of Corynebacterium pseudotuberculosis. Mol Microbiol. 1994;12:921-30.

56. Leiting WU, Jianping XI. Comparative genomics analysis of Mycobacterium NrdH redoxins. Microb Pathog. 2010:48:97-102.

57. Pacheco LG, Castro TL, Carvalho RD, Moraes PM, Dorella FA, Carvalho NB, et al. A Role for Sigma Factor $\sigma(\mathrm{E})$ in Corynebacterium pseudotuberculosis Resistance to Nitric Oxide/Peroxide Stress. Front Microbiol. 2012;3:126.

58. Silva WM, Carvalho RD, Soares SC, Bastos IF, Folador EL, Souza GH, et al. Label-free proteomic analysis to confirm the predicted proteome of Corynebacterium pseudotuberculosis under nitrosative stress mediated by nitric oxide. BMC Genomics. 2014;15:1065.

59. Samanovic Ml, Ding C, Thiele DJ, Darwin KH. Copper in microbial pathogenesis: meddling with the metal. Cell Host Microbe. 2012;16:106-15.

60. Wolschendorf F, Ackart D, Shrestha TB, Hascall-Dove L, Nolan S, Lamichhane $\mathrm{S}$, et al. Copper resistance is essential for virulence of Mycobacterium tuberculosis. Proc Natl Acad Sci U S A. 2011;25:1621-6.

61. Rowland JL, Niederweis M. A multicopper oxidase is required for copper resistance in Mycobacterium tuberculosis. J Bacteriol. 2013;195:3724-33.

\section{Submit your next manuscript to BioMed Central and we will help you at every step:}

- We accept pre-submission inquiries

- Our selector tool helps you to find the most relevant journal

- We provide round the clock customer support

- Convenient online submission

- Thorough peer review

- Inclusion in PubMed and all major indexing services

- Maximum visibility for your research

Submit your manuscript at www.biomedcentral.com/submit
Biomed Central 